\title{
Religion, Resources, and Representation
}

\section{Three Narratives of Faith Engagement in British Urban Governance}

\author{
Adam Dinham \\ Anglia Ruskin University, Cambridge, United Kingdom \\ Vivien Lowndes \\ De Montfort University, Leicester, United Kingdom
}

Faith groups are increasingly regarded as important civil society participants in British urban governance. Faith engagement is linked to policies of social inclusion and "community cohesion," particularly in the context of government concerns about radicalization along religious lines. Primary research is drawn upon in developing a critical and explicitly multifaith analysis of faith involvement. A narrative approach is used to contrast the different perspectives of national policy makers, local stakeholders, and faith actors themselves. The narratives serve to illuminate not only this specific case but also the more general character of British urban governance as it takes on a more "decentered" form with greater blurring of boundaries between the public, private, and personal.

Keywords: faith; faith-based organizations; governance; partnership; narrative

$\mathrm{B}$ ritish policy makers increasingly see faith groups as important civil society participants in urban governance. At regional, city, and neighborhood levels, faith groups are becoming involved in forms of cogovernance

\footnotetext{
Authors' Note: Thanks are due to the funders of the research projects on which this article draws: the U.K. Home Office ("Faith, Hope and Clarity: Developing a Model of Faith Group Involvement in Civil Renewal") and the Joseph Rowntree Foundation ("Faith as Social Capital"). Vivien Lowndes would like to thank Rachael Chapman for her contribution to the Home Office project. Adam Dinham would like to thank the other members of the Joseph Rowntree Foundation research team (Robert Furbey, Richard Farnell, Doreen Finneron, and Guy Wilkinson). We would also like to thank those who participated in the research for sharing their ideas and time so generously. Please address correspondence to Professor Vivien Lowndes, Local Governance Research Unit, De Montfort University, Leicester, LE1 9BH, UK; e-mail: vlowndes@dmu.ac.uk.
} 
(including formal partnerships and informal networks) alongside elected and appointed politicians, community representatives, and commercial interests. Faith groups are also being targeted as partners in "civil renewal," a policy agenda to stimulate and support volunteering and community leadership-as assets in their own right and as part of a broader process of capacity building (Blunkett 2004). In addition, faith groups are seen as having an important role in the delivery of urban services-whether through prestige projects, such as the new "city academies," (secondary schools) or a multitude of neighborhoodlevel coproduction initiatives (such as elders' lunch clubs, child care facilities, and community development projects).

In British urban governance, faith involvement is linked to policies of social inclusion: It is seen in part as a route into hard-to-reach minority communities. Faith groups have been seen by government as key agents in promoting "community cohesion" in the wake of the 2001 disturbances in the north of England and the associated critique of multiculturalist public policy, seen by some as condoning "parallel lives" among different ethnic communities (Cantle 2005). Post-9/11 and the London bombings in 2005 (7/7), government concern about radicalization within minority communities has added a new urgency to the strategy. In contrast to the United States, engagement with religious groups is associated in British policy discourse as much if not more with minority faiths as with Christian churches.

This article draws on primary research to take a critical and explicitly cross-faith look at the dynamics of faith involvement in urban governance. Focusing on cogovernance initiatives (rather than faith-based service delivery), the research reveals the absence of any shared paradigm. ${ }^{1}$ Different stakeholders-national policy makers, local partners, and faith groups themselves - tell quite different stories about faith engagement in urban governance. Differences relate not simply to matters of detail (how much, how often, by what means) but to the underlying rationale and purpose of faith involvement. We use the concept of narrative to refer to these distinct and contrasting attempts to link ideas, actions, and institutions within the governance arena (see Bevir and Rhodes 2003, 2006; Bevir 2005).

The article starts with a discussion of policies to engage faith groups in British urban governance. It goes on to problematize the idea of a "faith sector," seeking to specify the different actors and roles implicated by these policies. The main part of the article is an exposition of three contrasting narratives of faith engagement, based upon resources, religion, and representation. The analysis highlights the significance of differences in perspective between actors and their implications for policy and practice. The narratives serve to illuminate not only the particular case of faith engagement 
but also the more general character of British urban governance as it takes on an increasingly "decentered" form (Bevir and Rhodes, 2001), in which boundaries between the public, private, and personal become ever more blurred (Newman 2005, 2007).

\section{Faiths and Civil Society in Britain}

Most research on faith and civic engagement comes from the United States and is concerned with Christian churches (see Burns, Schlozman, and Verba 2001; Putnam 2000; Verba, Schlozman, and Brady 1995). In Britain, the intersection of secularism and multiculturalism creates a unique context. Christianity is the main religion in Britain (72\%); people with no religion make up $15 \%$ of the population; $5 \%$ of the population belong to a nonChristian denomination (half of whom are Muslims) (Office of National Statistics 2004). Just 10\% of British people attend church regularly, with attendance more common among women and middle-class people. However, attendance is growing in some urban areas, particularly among Black-led and Pentecostal churches. But despite small congregations, the Church of England remains a strong focus for community activity within many localities.

The religious makeup of some British cities varies considerably from the national profile. In Leicester, for instance, $45 \%$ of people identified themselves as Christian, $15 \%$ as Hindu, $11 \%$ as Muslim, and $17 \%$ as having no religion. ${ }^{2}$ The relationship between faith and ethnicity is complicated: In Leicester, the Indian community has Hindu, Muslim, Sikh, and Jain elements, while the Muslim community includes citizens whose origins are in countries in Asia, Africa, and East/Central Europe.

Despite debates about secularization, religion remains an important arena for civic participation and volunteering in Britain. Of respondents to the U.K. Home Office's Citizenship Survey, 23\% have participated in volunteering in a faith-based context (Home Office, 2005a). Such volunteering is of proportionately greater significance for women than men and for minority ethnic groups vis-à-vis White citizens (63\% of Black people and $59 \%$ of Asian people) (Home Office, 2005a). Taking all volunteering activity, religious affiliation itself does not make much difference, but those who actively practice a religion are more likely than others to volunteer. The same pattern can be seen in terms of civic engagement more generally, including participation in consultations and lobbying and involvement in decision-making bodies (Home Office 2005a; National Council for Voluntary Organisations 2007). 
Among faith groups, individual commitments are matched by collective endeavor in the urban arena. A survey conducted in Greater London identified more than 2,000 faith-based social action projects in the city, employing 3,000 people, supported by 13,500 volunteers, with 120,000 beneficiaries. The total figures are likely to be far higher, given that the response rate from worshipping communities was just under 30\% (London Churches Group 2002). A similar study in Leicester identified 250 faith groups supporting 450 different social projects (with a response rate of 67\%) (Leicester City Council 2004). Such projects address a wide range of issues (homelessness, racism, crime, drug and alcohol abuse, health, skill development, and culture) and user groups (elders, children, and young people; hard-to-reach communities) (Northwest Regional Development Agency 2005; Dinham 2007).

\section{Faith Engagement in Urban Governance: The Policy Context}

The British government's interest in involving faith groups in urban governance has grown from the early 1990s. This has taken place in the context of a broader agenda for partnership and democratic renewal at the local level, together with a perception that faith communities have been underrepresented in governance arrangements aimed at facilitating civil society engagement. As late as 2000, a government report referred critically to "the invisibility of faith communities in public life" (New Deal for Communities $2000,6)$. Faith groups are increasingly called upon to become actors in what Gerry Stoker calls "networked community governance," in contrast to both traditional elected local government and "new public management" (Stoker 2004, 11). The distinctive character of this form of urban governance lies in its broad repertoire of delivery mechanisms, which seeks to combine the diverse knowledge and resources of stakeholders in the public, business, and community spheres (Stoker 2004, 11). ${ }^{3}$

The organic growth of local partnerships in the early ' 90 s has been supplemented (or even overridden) by the push under Labour governments since 1997 to promote stakeholder collaboration in urban governance (and public policy more generally). At least 5,500 local partnership bodies were estimated to exist in 2002 , spending approximately $£ 4.3$ billion a year and focusing on issues including health, social care, crime prevention, housing, and environmental sustainability (Sullivan and Skelcher 2002, 24-27). In 2001, the government established a new tier of Local Strategic Partnerships (LSPs), charged with the strategic oversight of this burgeoning partnership activity. 
LSPs are required to make specific efforts to involve and consult faith communities, and a survey in 2004 found that faith representatives were involved in $71 \%$ of LSPs and part of the core membership in $46 \%$ (Office of the Deputy Prime Minister 2005). A report for the Church Urban Fund has recently argued that LSPs are "the only form of local public partnership that has really endorsed the concept of 'faith representatives' being there to represent the constituency of local faith communities" (Church Urban Fund 2006, 3). A contrast is drawn with experience in the National Health Service, where some nonexecutive directors on primary care trusts are identified as faith representatives but tend to see themselves as "people of faith" rather than spokespeople for a specific constituency (Church Urban Fund 2006, 3).

City councils have been encouraged to include faith communities in local compacts with the voluntary and community sectors and in consultations on local services-from education to policing (Lowndes and Chapman 2006). Faith engagement in neighborhood-level governance structures has also become a feature of some urban regeneration programmes (Neighbourhood Renewal Unit 2004; Local Government Association 2002). At the regional level, multifaith forums have been established, providing a source of representation on regional assemblies as well as opportunities for networking between different cities.

The push to bring faith groups into the partnership fold relates to a perception among policy makers of untapped resources in relation to community leadership and representation, community knowledge, and community assets. This has been linked particularly (but not exclusively) to improving the governance and welfare of minority communities and to strategies to improve community cohesion across ethnic lines (Home Office 2005b; Community Cohesion Panel 2004; Commission on Integration and Cohesion 2007). But, more broadly, the government sees faith groups as important players in its efforts to foster active citizenship and community development. ${ }^{4}$

But the engagement of faith groups in urban governance is not simply a top-down policy agenda. Faith bodies themselves have entered the policy debate to highlight the important role they play in supporting urban communities (Commission on Urban Life and Faith 2006). The Commission on Urban Life and Faith (led by the Church of England but including other faiths) has recently argued that "faithful capital" is of increasing significance in the context of "rapidly increasing ethnic and cultural diversity" and the current "heightened fear of the stranger" (Commission on Urban Life and Faith 2006, 1). Responding to these changing contexts builds upon a long history of faith involvement in urban social action-from the institutional provision of services (in education, housing, and social care) to 
volunteering and charitable giving. Such activity is inspired, even required, by diverse faith traditions-including the Christian ideas of community and love of neighbor, the Jewish practice of mizvah, the Muslim duty of zakat, and the Hindu concept of seva.

\section{Faith Engagement: Who, Where, and Why?}

Engaging faith groups is clearly part of a broader "third way" government strategy to mobilize the resources of civil society in pursuit of citizen well-being and better governance (Giddens 1998). But there is also an assumption that faith groups have special qualities that enable them to play a distinctive role in urban governance. Rationales for faith group involvement have rarely been spelled out; they have been implicit, sometimes contradictory, and often downright opportunistic. Important questions remain unanswered. Who in the faith sector is expected to do what - and why? Indeed, is there any such entity as a faith sector, and how is it different from the wider "voluntary and community sector"? Is it likely that faith groups will wish to be involved in urban governance, and what sort of support might they need? Are policy makers and local stakeholders equipped to maximize the benefits and anticipate the pitfalls of faith engagement? This article seeks to illuminate such issues.

Reflecting the current state of debate, we have so far used a variety of different terms to describe faith involvement in urban governance. Terms such as faith based, faith group, and faith community tend to be used interchangeably in the British policy debate. But it is important to try and identify the range of different actors and roles bundled up in these portmanteau terms. This is the purpose of Table 1. Faith involvement in wider civil society can be seen as taking place along a continuum that starts with faith communities in a very general sense and moves through faith organizations, faith networks, faith leadership, and faith representation. The roles identified do not, of course, exhaust the full repertoire of faith-based social action, which (as we shall see later) may be far more broadly based than policy makers envisage. Rather, Table 1 seeks to uncover who in the faith sector is doing what and to draw parallels with the roles played in urban governance by other, more familiar civil society actors (e.g., political parties and voluntary and community organizations).

Table 1 is derived from original research undertaken for the U.K. Home Office in Leicester - a city of 288,000 in the East Midlands region of England (see Lowndes and Chapman 2006 for a full account). With its ethnically 
Table 1

Mapping Faith Involvement in Civil Society and Public Policy

\begin{tabular}{|c|c|c|}
\hline Faith Actors & Role in Urban Governance & $\begin{array}{l}\text { Examples from Leicester, } \\
\text { United Kingdom }\end{array}$ \\
\hline Faith communities & Citizens & $\begin{array}{l}\text { Christians, Muslims, Hindus, } \\
\text { and others }\end{array}$ \\
\hline Faith organizations & Members & $\begin{array}{l}\text { (a) Places of worship } \\
\text { (b) Religious associations } \\
\text { (c) Federations of groups } \\
\text { (d) Community projects }\end{array}$ \\
\hline Faith networks & Intermediaries & $\begin{array}{l}\text { (a) Sector networks: } \\
\text { Faith Regeneration Network, } \\
\text { Regional Faith Forum } \\
\text { (b) Topic networks: dialogue } \\
\text { groups, including } \\
\text { Muslim-Christian Women's } \\
\text { group, Muslim-Hindu group }\end{array}$ \\
\hline Faith leaders & Leaders & $\begin{array}{l}\text { (a) Formally constituted: Council } \\
\text { of Faiths } \\
\text { (b) Informally convened: Faith } \\
\text { Leaders' Forum, Multicultural } \\
\text { Advisory Group }\end{array}$ \\
\hline Faith representatives & Partners & $\begin{array}{l}\text { (a) Service-based: advisory groups } \\
\text { for police, health, education, } \\
\text { etc. } \\
\text { (b) Governance-based: strategic } \\
\text { partnerships (LSP and regional) }\end{array}$ \\
\hline
\end{tabular}

Source: Adapted from Lowndes and Chapman 2005.

Note: LSP = Local Strategic Partnership.

diverse population and strong interfaith traditions, Leicester is not a typical case study, but it does prove a useful "research laboratory" for testing out conceptual tools. During 2005, 27 semistructured interviews were carried out, and three meetings were observed. Respondents were national faith leaders and civil servants, faith leaders, and activists in the city of Leicester and practitioners in the local authority and police force. ${ }^{5}$

We set the Leicester research in context by drawing on additional primary research undertaken as part of a project on faith and social capital for the Joseph Rowntree Foundation, which was carried out in London, the West Midlands, the Northwest, and Yorkshire (see Furbey et al. 2006). In 2005, 24 semistructured interviews were conducted, focusing on people 
identified as faith leaders (including clergy and laity) but also including activists, service users, and other informal participants. There were also nine group interviews, involving a total of 31 participants from 25 faithbased organizations. ${ }^{6}$

The term faith community has been criticized on two fronts. First, the term has "homogenizing" tendencies because it "fails to capture the diversity between, and also importantly within, faiths," and second, it is increasingly replacing the term "black and ethnic minorities," coming to refer to people of minority faiths, indeed specifically (but not explicitly) to Muslims (National Council for Voluntary Organisations 2007, 2). In the wake of 9/11 and the subsequent London bombings, faith is being discursively constructed as a property of the "Other." Just as the concept of ethnicity has over time became associated with minority communities, so too is faith coming to denote something outside the "norm" of Britishness. There is a current within public discourse in Britain in which only Muslims have faith - and a potentially dangerous faith at that. As Ted Cantle $(2007,1)$ has recently speculated, "If faith is the new race, is faithism the new racism?"

According to our typology, faith communities are understood as being made up of individual citizens and their family and social networks who have a religious identification or affiliation and may or may not take part in regular worship (whether Christian, Muslim, Hindu, etc.). Faith communities are constituted through the "shared beliefs, values and practices" that "bind people together, giving them a shared sense of belonging" (National Council for Voluntary Organisations 2007, 2). Although faith identities are transmitted in part through formal religious settings, they are also influenced by common cultural references and "inherited" through family and community membership. Faith communities are places where citizens can take opportunities (and support) to become involved in civil society through volunteering, befriending, and so on. Indeed, as seen above, levels of volunteering are higher in Britain among those who actively practice a religion. But there is no link between religious affiliation per se and being an active and engaged citizen.

Opportunities for active citizenship may be provided by or channeled through faith organizations. These include places of worship (a church, mosque, or temple), religious associations (such as the Catholic Knights of St Columba), community projects (e.g., for older people), and federations of groups associated with a particular religion (e.g., the Federation of Sikh Organizations in Leicester). Citizens are members of faith organizations, as they may also be members of other community groups or voluntary associations or of political parties or trade unions. 
Faith organizations contribute to urban governance through the opportunities they offer their members for capacity building, community development, and coproduction. As Furbey et al. $(2006,26)$ put it, "faith communities, through their organizational structures, bring people together in associations that are developmental and strategic" (emphasis added). Such organizational structures are diverse in scale and scope, ranging from religious congregations and places of worship to semiprofessional and professional organizations that employ staff, handle large budgets, and deliver a range of urban services.

For any community body to exercise influence within urban governance more widely conceived, it needs vehicles for the mobilization of citizens beyond their immediate locale and specific interests. This is the role of faith networks, which act as intermediaries between leaders and citizenmembers. Drawing on Chris Baker's $(2007,5)$ distinction, we can see faith communities as reservoirs of "spiritual capital" (theological identity, values, and moral vision), which is potentially - but not inevitably-a resource for urban governance. An institutional infrastructure of faith organizations and networks is a prerequisite for spiritual capital to be converted into "religious capital," defined by Baker $(2007,5)$ as "the practical contribution to local and national life made by faith groups." Elsewhere, we have identified the importance of civic infrastructure in determining whether forms of social capital become mobilized as resources for urban governance (rather than simply sustaining the well-being of individual communities). Whether faith based or not, civic infrastructure refers to the formal and informal mechanisms that link different community-based organizations one to another and provide channels for (two-way) communication with citywide policy makers (Lowndes, Pratchett, and Stoker 2006).

Our research reveals that faith networks may be more or less formal and may be present across the spectrum of actors or focused on a particular topic or issue. (Leicester has a Faith Regeneration Network covering a full range of community issues and five informal "dialogue groups," including a MuslimHindu group and a Christian-Muslim women's group.) Some networks arise organically in response to local needs and are galvanized by local activists; others are creatures of government policy and funding (associated, for instance, with the "community empowerment networks" established after 1998 in the 88 most disadvantaged urban areas in England). Some are hybrids of both, starting life as organic networks and responding (or sometimes being diverted) to policy needs. In either case, faith networks are potentially arenas in which different faith organizations can exchange ideas and information, argue about priorities, agree on positions, make alliances, and "do deals." 
Faith networks are the organizational expression of the "constituency" served by faith leaders and representatives. Here, they can find out the views of member-citizens, playing a role in framing debate, mediating between different viewpoints, brokering conflicts, and feeding back higher level decisions. They may act as (imperfect) vehicles of accountability.

Such networks are the institutional equivalents to political parties, trade councils, or councils of voluntary service; they are secondary associations in the Durkheimian sense-arenas within which preferences are deliberated, identities forged, and alliances negotiated. In Britain, political parties and trade unions have declined (even collapsed) as important nodes of civil society, that is as mass-membership organizations based upon face-to-face community-based meetings (though they continue, of course, to play other important roles in the polity and economy). Faith networks offer an arena in which citizens of different ages, social classes, and ethnicities come together to debate and arrive at common positions on a wide variety of topics (they are not single-issue organizations). They may have an important potential role to play in the "new collectivism" envisaged by British intellectuals of the left (Crouch and Marquand 1995).

All faith groups have their own leadership arrangements, but what about leaders of a broader faith sector engaged in urban governance? Our research showed that faith leadership may be formally organized (e.g., the Leicester Council of Faiths), with a constitution, subscriptions, and elected officers, or informally convened (the Faith Leaders' Forum and the Multicultural Advisory Group), with a shifting membership and an ad hoc meeting schedule. These bodies provide a vehicle through which the faith leadership can be consulted on both an ongoing basis and on specific issues and incidents (where informal forums are particularly helpful).

In our typology, leaders become faith representatives when they act as partners in urban governance. Through their representatives on urban partnerships, members of faith communities are enabled to participate in the planning and delivery of urban services-from consultation to cogovernance. In Leicester, for example, the Council of Faiths provides faith representation on bodies such as the Education Committee of Leicester City Council, the Leicestershire Faith and Health Forum, and the Police Advisory Group on Race Issues. There is also a faith sector representative on the LSP and the East Midlands Regional Assembly. The existence of diverse and overlapping organizational arrangements is generally regarded as a positive aspect of Leicester's approach to faith involvement and as playing an important role in sustaining good community relations. Our research suggested that a range of different settings for dialogue, alongside 
multiple channels of communication, can maximize flexibility, responsiveness, and inclusion.

\section{Agency and Narrative in Faith Engagement}

Table 1 provides a useful means of locating agency within the amorphous and undifferentiated category of "faith," but it should not be interpreted as implying a smooth conveyor belt from worship to governance. The purpose of Table 1 is to open up the black box of faith-to look inside at who does what and how this relates to public policy objectives. The activities and roles in Table 1 occur in parallel as well as in sequence, and there may be disconnections as well as linkages between them.

Table 1 serves also to debunk the idea that faith communities per se can act as partners in urban governance. Faith engagement in governance takes place only through the exercise of agency-through the reflexive and contextspecific actions of individual citizens of faith, members of faith organizations and faith networks, faith leaders, and faith representatives. Believers who attend a Hindu temple may also volunteer to organize a community festival. Members of a Muslim women's organization may make representations to the local council or join with other women's groups in a local campaign. A Catholic priest may preach to his congregation and run a lunch club for local elders (of all or no faiths), while also being part of a neighborhood forum or a citywide interfaith council. The Sikh chair of the interfaith council may sit on the board of the citywide LSP and be a member of the regional faiths forum; at the same time, he or she may (or may not) play an active role in the local gurdwara (Sikh temple) and associated neighborhood activities.

None of these connections is necessary or inevitable. Inspired by decentered conceptual models, we see governance as "the contingent product of political struggles, embodying competing sets of beliefs" (Bevir 2005, 3). Influenced by their own social context and narrative traditions, actors make different links between beliefs, action, and the institutional environment (Bevir and Rhodes 2006, 4). People of faith employ their own "local reasoning" (Bevir and Rhodes 2006, 9) to confront the opportunities (and/or threats) presented by the public policy agenda to engage with faith. Beliefs and practices (including traditions of social action) vary within and between different faith communities, which are also influenced by one another, whether through opposition or collaboration. Public agency, including engagement in urban governance, is differently "situated" (to use Bevir and 
Rhodes' terminology) for British Christians, Hindus, Jews, Muslims, Sikhs, and so on. Moreover, there are important differences of perspective within the main faiths themselves, related to issues of doctrine, values, generation, and gender. It is individuals, not institutions, who "act creatively for reasons that make sense to them" (Bevir and Rhodes 2006, 72), but such action takes place in a specific social context.

Does recognition of this complexity preclude further analysis? No, because it actually directs attention to an important insight, namely, "patterns of governance arise as the contingent constructions of several actors inspired by competing webs of belief formed against the background of diverse traditions" (Bevir and Rhodes 2006, 166). Understanding governance in this way requires a narrative approach, which records and critically analyses diverse "governance stories." Such stories

explain shifting patterns of governance by focusing on the beliefs and actions by which a host of people construct varied practices. They explore some of the diverse ways in which situated agents are changing the boundaries of state and civil society. (Bevir and Rhodes 2006, 166)

From our in-depth qualitative research, we were able to identify three distinct stories of faith and urban governance: the "resources" narrative of national policy makers, the "religion" narrative of faith actors, and the "representation" narrative of local stakeholders. Notwithstanding some internal differentiation, the three narratives embody and express a distinctive reasoning regarding the purpose of faith engagement and the relationships between the roles and activities identified in Table 1.

The elaboration of narratives involves more than just recounting actors' own statements. Narratives are not, in Atkinson's (2000) words, "immediately accessible" (p. 213); moreover, they may conceal as well as reveal meaning (given that they express certain interests). The researcher is engaged in the interpretation of interpretations (Bevir and Rhodes 2006) or what Jameson (1989) calls an "allegorical act" (p. 10). Through the careful coding and comparison of themes, the researcher seeks to identify different layers of meaning in a text (an interview transcript or a policy document, for instance) and to identify the underlying "master code" (Jameson 1989, 10) or "story line" (Hajer 1993, 47). In a process similar to triangulation, the researcher moves closer to this through establishing "discursive affinities" (Hajer 1993, 47) among a variety of texts. Observational methods are also used to study the practices and interactions that conform to and at the same time reproduce the narrative. 
As composite analytical constructs, our narratives are not the same as the stories told to us by research subjects. But they are both robust and resonant. To establish the validity of the findings, we used peer debriefing (with academic colleagues in our research teams) and member checking (with interviewees in a focus group situation) (Erlandson 1993). In this way, we were able to check that the narratives were "accurate, comprehensive and consistent" (Bevir and Rhodes 2006, 29) and, moreover, resonated with the experience of those whom we were researching.

It is through the comparison of rival narratives, which now follows, that an interpretivist methodology seeks to generate "objective" knowledge about the issue at hand (Bevir and Rhodes 2006, 28). We present the narratives in textual form but also graphically, using an organizing image (Morgan 1986). Different narratives represent different ways of seeing and understanding the world; they are partial in both senses of the word-they focus on just some aspects of a phenomenon, and they reflect specific interests and preferences. But as Gareth Morgan (1986) explains, "the process of framing and reframing itself produces a qualitatively different kind of understanding that parallels the quality of binocular vision" (p. 40).

\section{Resources for Urban Governance: The Policy Narrative}

"The church is the biggest voluntary sector organization in the countryit's a cheap way into anywhere."

We start with the policy makers' narrative, which focuses upon the resources that faith groups can bring to urban governance. The quotation above, from a senior civil servant, reveals a preoccupation with the untapped organizational capacity of faith groups and with their potential role in reaching socially excluded groups ("anywhere"). The narrative resonates with a bureaucratic tradition that stresses hierarchical authority and functional specialism. As Figure 1 shows, its organizing image is a pyramid.

The policy narrative sees faith communities as "repositories" (Home Office 2004) of resources for addressing issues of public significance, including urban governance in general and the more specific issues of community cohesion and the prevention of religious extremism. Faith group resources may take the form of human capital (e.g., staff, volunteers, and members), social capital (e.g., networks of trust and reciprocity), physical capital (e.g., community buildings and venues), and financial capital (e.g., collections, subscriptions, and donations). 


\section{Figure 1}

The Policy Narrative

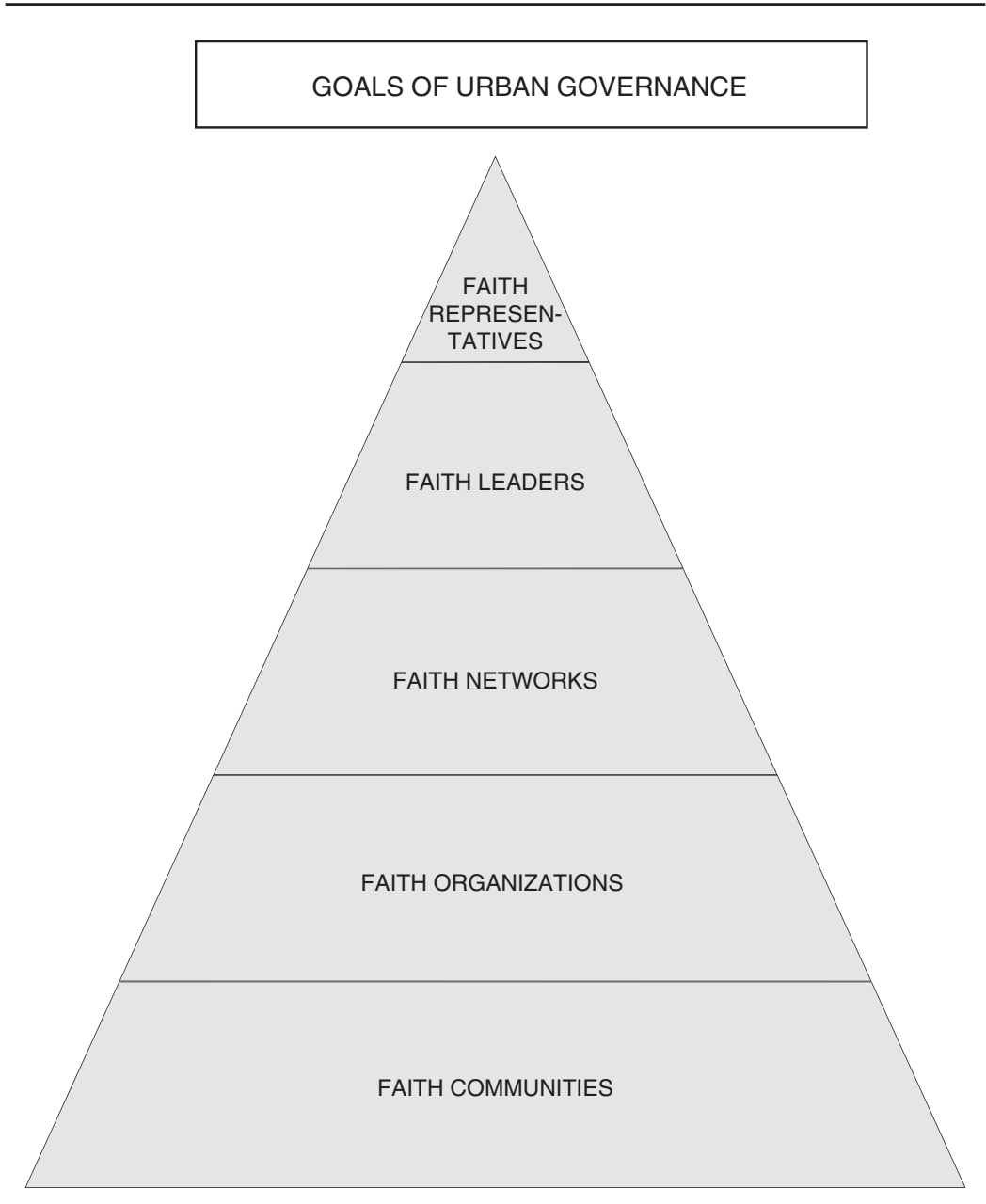

The policy narrative is instrumentalist in its regard for faith communities as "useful" because of what they can "produce" in terms of social "goods." The policy narrative understands faith communities as a general resource for adding value in a secular context. The aim of faith engagement is to improve the quality of urban governance; the "faithfulness" of faith communities is of secondary and limited (or even no) significance. A Church of 
England activist argued forcefully that 'the government doesn't want to hear about what makes us faithful people. They'll fund us if we don't do anything religious with the money."

The clarity of policymakers' goals may obscure the realities of faith communities' own aspirations and motivations and, in so doing, assume a model of engagement which is not reflected in practice. The policy narrative suggests that faith communities are the bedrock of other faith-related activities that are orientated toward the policy goals outlined above. It assumes that religious organizations naturally contribute to the formation of networks, whether local interfaith forums or national bodies such as the Faith Based Regeneration Network. Such networks are seen as part of a movement toward strategic engagement with governance issues, through faith leaders and representatives sitting as representatives of a faith sector on urban partnerships. But the linearity of this narrative implies a neatness and directedness within faith communities that empirical evidence suggests is unlikely to be the case (for example, see Furbey et al. 2006). In particular, the assumption of continuity between the worshipping community and faith leaders and representatives is, at least, contested.

Another implication of the policy narrative is that single-faith communities at the grassroots level will move toward the engagement of many faiths as they network among each other and leaders and representatives emerge. This is an especial concern of the community cohesion policy agenda. This assumption may be misleading because it takes no account of the power and capacity differentials between faith traditions. Indeed, while engagement may be relatively easy for a large, highly organized, and wellresourced faith tradition, such as Anglican Christians, for smaller traditions, such as Jains, Baha'I, or Zoroastrians, involvement is likely to take a very different character. Some faith groups may prefer to act on a single-faith basis for practical or theological reasons.

More generally, the top-down assumptions of this narrative are contested. While policy makers envisage the mobilization of faith group resources in the pursuit of urban governance objectives, faith groups themselves may focus on the extent to which they can access or add value to government resources, for instance, for new buildings, training, or project running costs. Like all community bodies, faith groups experience difficulties in recruiting volunteers because of constraints of time, skills, and confidence. Donations and subscriptions can also be hard to maintain in the context of dwindling congregations (for some faiths) and in disadvantaged communities (in others). Buildings can become as much of a burden as an asset to faith groups, given the costs involved in renovation and adaptation, 
especially where they are heritage buildings (Dinham and Finneron 2002 PLS PROVIDE REF OR DELETE IN-TEXT CITE).

A critical examination of the policy narrative illuminates a number of key debates. First, the notion that faith communities are repositories of social goods cannot be assumed. In some cases, faith communities may be places of disconnection, insularity, and radicalism. Second, the assumed linearity and continuity of relationships between faith communities, organizations, networks, leaders, and representatives are debatable and may be highly differentiated between and within faith traditions. Different faith groups also vary in terms of their capacity for engagement in urban governance and in the multifaith platforms that usually support this. Third, it is far from established that the urban policy goals associated with faith engagement are actually shared by people of faith themselves, whose priorities and aspirations may be very different. Fourth, resources flow along a two-way street: What are faith groups contributing toward urban governance, and what additional resources do they require to maintain, expand, or redirect their work?

\section{Religion and Urban Governance: The Faith Narrative}

"I am doing this for the benefit of the community and what I believe in."

The faith narrative starts from the perspective of faith communities themselves and while incorporating the same actors and roles, presents a stark contrast to the policy narrative. In placing faith communities at the center of the narrative, the priority is shifted away from a linear, goaloriented journey from faith communities toward social goods and on to the various activities undertaken by faith communities as goods in themselves. Such activities may overlap with the objectives of urban governance, but they are motivated by religion itself, as indicated in the quotation above from a Muslim community leader. Figure 2 shows the relationships embodied in the faith narrative, using the image of a web.

Faith communities are at the center of the web, linked in two-way (and provisional) relationships with other forms of faith-based activity (organizations, networks, leadership, and representation) and with the world of urban governance. In this narrative, people of faith engage in such activities, if at all, as a matter of personal and collective choice. Whereas the policy narrative is driven by the desire to identify and harness faith group resources in pursuit of urban governance goals, the faith narrative places such goals in the context of their own broad repertoire of internal and external 


\section{Figure 2}

\section{The Faith Narrative}

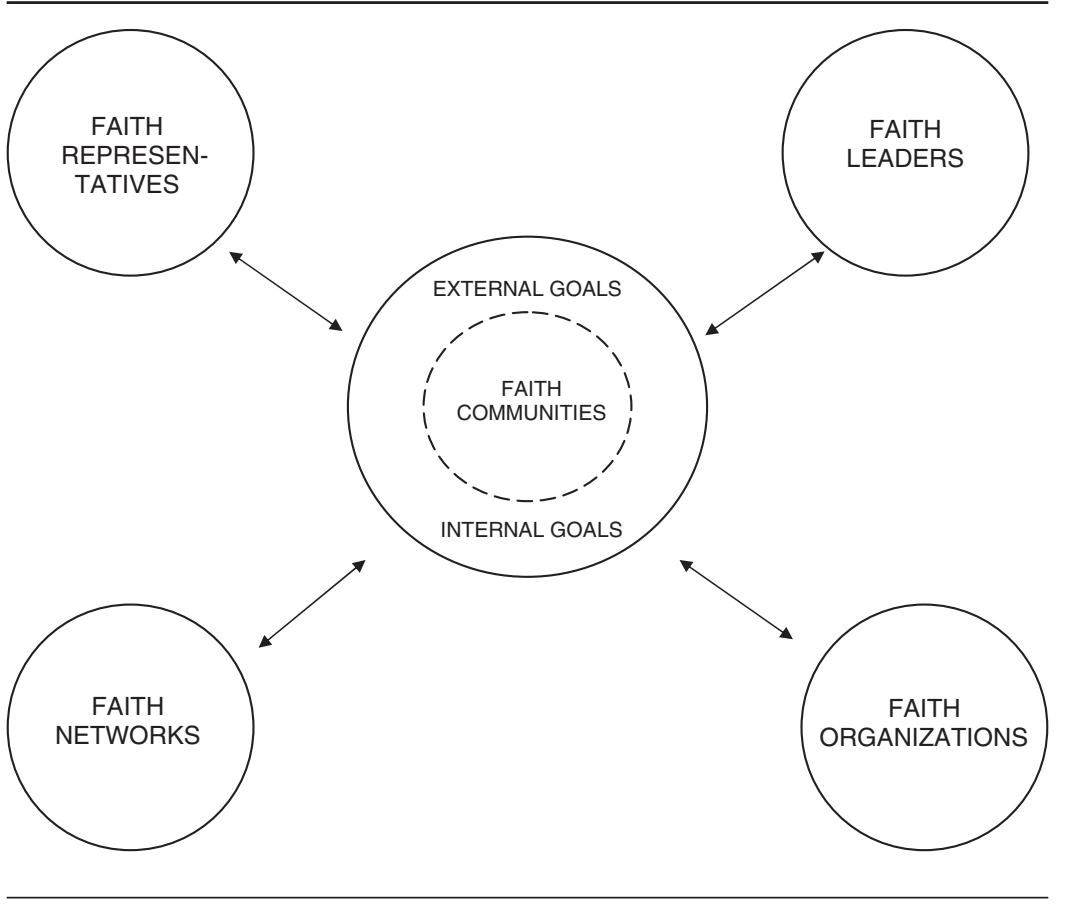

aspirations. There is no necessary or even obvious connection between faith activity and urban governance.

In this narrative, there is no assumption that those who believe or worship are also members of faith-based organizations or active as community networkers. These linkages are contingent and context specific. Similarly, those engaged in faith leadership and representation do not have taken-forgranted connections with faith communities. Leaders cannot assume that they have authority vested in them (and the knowledge and contacts to exercise this effectively) simply because they are at the top of a pyramid of evermore specialized roles. This narrative is not premised upon the existence of a coherent and structured faith sector. Indeed, a comparison of the religion and resources narratives suggests that the faith sector is essentially a discursive construction of policy makers 
In this narrative, the focus-unsurprisingly perhaps-is on religion. The faith community is seen primarily as a place of belief, worship, and fellowship rather than as a repository of resources for the pursuit of policy goals. Faith communities may engage in projects and associations, networks and partnerships, or any combination of these. They may produce leaders and representatives in public spaces. But their goals are highly variable and derive from the primary fact of being in or of a faith community rather than being policy or socially oriented. Thus, in Figure 2, examples of possible goals are given in two spheres-external and internal.

Goals in the external sphere may relate to the extension of the faith community evangelically. Where goals are linked to public policy, it cannot be assumed that faith actors will adopt the linear reasoning of the policy narrative. Indeed, Furbey (2006) has contrasted "cuddlesome" and "troublesome" (p. 1) faith engagement: The former are willing partners and consultees in urban governance, while the latter are oriented toward critical campaigning and self-organization in pursuit of broader social justice goals. But of course, faith communities may not be externally oriented at all. Their goals may be within the internal sphere alone, focusing on the faith community itself: on the relationships, fellowship, prayer life, or spirituality of the community and its members. But what links the internal and external goals of faith communities is their value base. In our research, faith actors explained their involvement in urban governance in terms of the "outworking of their faith." 10 As an LSP faith representative put it, "it is the values that come from being a member of a faith that is important, the belonging, the discipline ..."11 This is the "spiritual capital" identified by Chris Baker (2007, 5), which has the potential (but not inevitable) capacity to galvanize practical contributions to the wider public realm.

An example of the faith narrative is provided by the report from the Commission on Faith and Urban Life, Faithful Cities, which proposes a "value-driven approach" to "building the good city" (Commission on Urban Life and Faith 2006, 62). The report argues that fundamental questions about what makes a fulfilling human community are generally avoided by policy makers, despite their language of "sustainable communities." The faith narrative exhibits a degree of reflexivity not present elsewhere. There is an awareness of the importance of language and culture and of its potentially oppositional nature. As Faithful Cities puts it, "the language of 'love,' 'hope,' 'judgement,' 'forgiveness,' 'remembrance' and 'hospitality' combine to form a distinctive 'story' . . that challenges dominant definitions in public policy" (Commission on Urban Life and Faith 2006, 3 ). Interestingly, we found a high degree of convergence among different 
faiths in relation to the specific values identified as relevant to their engagement in urban governance.

Involving faith groups in urban governance brings with it an explicit debate about values - and the possibility (even likelihood) of value conflict. Such debates may challenge policy makers and practitioners because they surface values that are usually submerged for political reasons (e.g., the redistributive aspects of some government policy) or because they involve a direct challenge to public policy norms (from equal opportunities to short-term target-driven funding). Policy makers and practitioners are often uncomfortable with discussing values head-on, especially where explicit reference is made to religion. This is not to say that values are not important to policy makers. But there is clearly a dissonance between understated secular notions of a public service ethos (or alternatively, a commitment to market-oriented efficiency) and the vocalization of religious belief as a reason for and guide to public action. This vocalization may be one of the distinctive contributions that faiths make in their involvement in urban governance.

Faith engagement has the capacity to introduce what Janet Newman (2007) calls "troubling issues" (p. 27) into the public realm. Those involved in urban governance are not used to confronting issues of "the body, dress and comportment" (Newman 2007, 36). Will they want to pray? Do they need special food? Might she be wearing a veil? Do we need to take our shoes off? When are their festival days? Such questions illuminate the constructed nature of policy makers' own narratives - around the conduct of formal meetings, practices of informal networking, matters of status, and personal relations - and the ways in which these too can be exclusive and threatening to the outsider, including faith activists. At another level, such questions also raise the profile of personal and social issues that are unfamiliar in public space. What is the human dimension here? How will this contribute to people's sense of happiness? What are the choices that we ought to be making in the service of the "good" society?

Our research revealed a certain amount of cynicism among faith actors about the attempts of policy makers (and local practitioners) to hijack the normative agenda-for instance, claiming grassroots legitimacy on the basis of faith group involvement, without actually engaging with the values and practices of those groups. At the same time, some faith group representatives expressed concern that involvement with the institutions of urban governance could "corrupt" people of faith, distracting them from more fundamental goals. Indeed, the London Churches Group (2002) acknowledges that some faith groups do not regard such work as within their "calling" (p. 20). 
As we noted at the start of the article, new governance stories tend to break the bounds of normal policy discourse and in so doing, reveal the situated character of dominant narrative traditions. The faith narrative is especially provocative because of the challenge it presents to the established public/private boundary. It provides a lucid exemplar of Newman's (2007, 27) "rethinking the public" thesis. The faith narrative is, in effect, part of a wider civil society movement to "re-inscribe the public domain with values associated with the private and personal spheres" (Newman 2007, 33), although some faith actors may consider counterparts within, for example, feminist and gay movements to be unlikely coconspirators.

\section{Representation in Urban Governance: The Partnership Narrative}

"Faith-based organizations are trusted by people who would not trust, and would not approach, or even think of going to a statutory or another voluntary organization." 12

The third narrative starts from the perspective of faith communities as participants in local partnerships and is evident in the discourse of local stakeholders from the public, private, and voluntary and community sectors. The quotation above, from the secretary of an interfaith forum, identifies faith bodies as representing a specific (and hitherto marginalized) constituency within urban governance. Government advice on partnership formation in disadvantaged urban localities argues for

the need to incorporate the diversity of society into the mainstream. Faith communities represent a significant element of diversity - both by virtue of straightforward variety of faiths and because of the overlap between faith and ethnic or cultural identity. (New Deal for Communities 2000, 6)

This narrative is framed in the assumptions of what we have called elsewhere the "new local corporatism" (Lowndes and Sullivan 2004, 60), which binds the representatives of different interest or identity groups into a collective decision-making process. Local partnerships echo the best aspirations of national-level corporatist arrangements: the opportunity for inclusion of previously excluded stakeholders and the principles of consensusbuilding and shared ownership of decision making. But they also express some of the less realistic assumptions of the corporatist discourse, namely, that disparate individuals can be represented (and, indeed, disciplined) by 
Figure 3

The Partnership Narrative

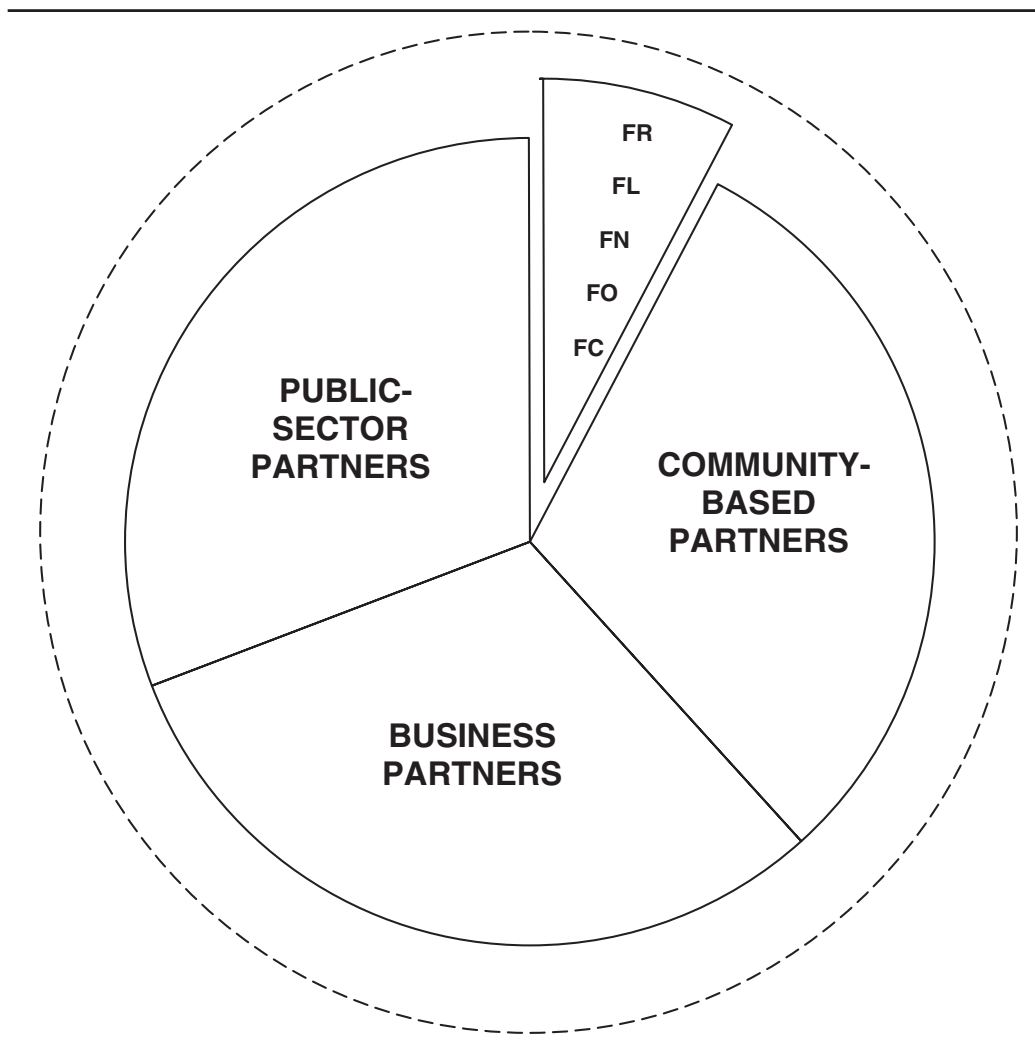

Goals of Urban Governance

representatives of umbrella organizations and that less powerful stakeholders will be able to exercise significant influence in the face of powerful vested interests (Lowndes and Sullivan 2004, 60-61).

The image of the partnership narrative is an orange, with segments representing different stakeholders (see Figure 3). The assumption is that these fit together neatly within a skin of shared urban policy goals. Each segment has a distinct identity but something more than the sum of the parts is created when they are placed together. As Chris Huxham (1996) has argued about partnership governance, "working together offers organizations the 
possibility for improved delivery of objectives, and the creation of new (often unanticipated) opportunities" (p. 1).

The partnership narrative assumes that the segments of the orange can be divided easily into three chunks - the public sector segment (the elected local council and other agencies such as health and police), the business segment (local companies, chambers of commerce, and privatized providers of urban services), and the community segment (including not-for-profit service providers, self-help and community action projects, and citizen groups). Faith engagement is seen within this narrative as one of the (newer) segments within the community chunk. Faith involvement may be seen as helping to diversify community representation, particularly in localities with high concentrations of minority faiths. Including faith actors is part of an attempt to go beyond the "usual suspects" in the community sector and to challenge the hold of professionalized "voluntary organizations" upon community representation (though many faith-based activities already understand themselves as existing within this professionalized domain).

At the same time, in some very deprived White working-class communities, such voluntary organizations may be notable by their absence. Indeed, the local Church of England vicar may be the only "community representative" left on a rundown housing estate. As someone with a stipend and a building and (at least some) links into the community, the vicar may play a key role in partnership activity in such areas.

Urban partnerships exist at many levels-from the LSP charged with the strategic governance of an entire city to a neighborhood-level partnership aiming to tackle antisocial behavior. As Figure 3 shows, the partnership narrative encompasses all these different levels: Faith communities are the pips at the center of the orange, with faith organizations, faith networks, faith leaders, and faith representatives all present on outer layers. Those actors nearer the external skin are those most concerned on a day-to-day level with matters of urban governance, working alongside leaders and representatives from the wider community sector and from government and business. At the same time, faith communities and faith organizations near the center also have their own partnership counterparts: community activists or front-line public servants and local entrepreneurs, operating near the skin but residing throughout. So when the Bishop of Leicester (for instance) sits on the LSP, there is an assumption that he has a relationship with faith communities (as his constituency) but also that faith actors at the neighborhood level will themselves be engaged in more local partnership activity.

The partnership narrative sees faith engagement as "topping up" or extending community representation. It aspires to better urban governance through 
greater social inclusion, drawing upon the specific knowledge, skills, and authority of faith leaders and representatives. The aim, in the words of a senior civil servant, is to "plug the governance deficit"13 in areas of multiple disadvantage where community leadership and citizen participation have traditionally been weak. Faith involvement is also increasingly linked to a search for better "community intelligence" about extremist threats within minority faith communities. The partnership narrative stresses the benefits of engaging moderates and of using this leverage to nurture a sense of collective belonging and civic responsibility within (specifically Muslim) communities.

The partnership narrative is open to criticism by those who question the representativeness of faith leaders. Indeed, those who sit on partnership bodies are themselves aware of these difficulties; as one LSP faith representative (from a Jewish background) explained, "my main difficulty is actually having sufficient contact with faith groups and getting feedback from them as to what they want and what they are interested in." ${ }^{14}$ In this way, this narrative risks implying a linear relationship between worshipping communities at one end and faith leaders and representatives at the other. It assumes the existence of a faith constituency, but we know that in reality, there are many different interests and identities at stake. The LSP representative argued that it is necessary to establish "a common denominator" and to ensure that a local faith network is more that just a "database of people." ${ }^{15} \mathrm{~A}$ key difficulty is in establishing something of value that is not simply a lowest common denominator. We encountered suspicion from nonfaith stakeholders that representatives only "looked after their own community"; there were also frequent comments that younger people and women were not properly consulted. Faith actors themselves also disputed what constitutes legitimate representation. For example, an activist from the Sikh community argued that "professional" Church of England representatives (clergy) were not really community leaders in the sense of being selected from within the community and accountable to it. He also expressed the view that Hindu leaders were almost exclusively from the Brahmin caste. ${ }^{16}$

Faith is a good example of the new "imaginaries of representation" which accompany "new spaces of deliberative, participative and community politics" (Newman 2005, 205). But, as Newman goes on to argue, we should not simply equate these imaginaries with "an expanded form of democracy" but rather question "their implications for patterns of inclusion, exclusion, voicing and silencing and for the reconstitution of identities and interests" (Newman 2005, 205). The notion that this might add up to something representative of faiths risks concealing many of those voices behind the impression that they have been heard. A Muslim leader suggested 
to us that the idea of a faith sector was best regarded in aspirational terms: "At some time in the future, you may well have something that's a faith sector, where people who believe in a higher spiritual being can come together." ${ }^{17}$ Another Muslim activist concluded that "It is a dilemma for government.... Who do you speak to and how do you ascertain that they're an authentic voice? . . Maybe it's just about speaking to lots of different people rather than trying to speak to one person only." ${ }^{18}$

\section{Toward a New Discourse Coalition?}

This article has reviewed the policy context for faith engagement in British urban governance. It has also sought to specify the different roles and activities through which people of faith become engaged, differentiating between faith communities, faith organizations, faith networks, faith leaders, and faith representatives. The article has questioned the idea of a homogenous faith sector able (or willing) to act in an autonomous and standardized fashion within the public policy arena. Drawing on the concepts of situated agency and narrative tradition, we have argued that faith engagement is understood differently by different stakeholders-faith communities themselves, national policy makers, and local partners. There is, as yet, no shared paradigm. Different stakeholders tell quite different stories about faith engagement, each making specific assumptions about the way in which beliefs, actions, and institutions are linked. Three narratives have been explored, with the recognition that each is itself internally differentiated (between and within faith communities). These patterns of differentiation are a topic for further research.

Our study of faith engagement has wider relevance for understanding urban governance. Bevir and Rhodes (2006) argue that contemporary governance does not have a defining essence but is best understood through "decentred studies of the diverse practices of which it consists" (p. 169) They propose that such studies should focus upon varied political actors and political practices - from prime ministers to individual citizens, from parliaments to forms of protest. Our research is offered in this spirit. Governance stories are played out by Methodists and mullahs as well as councillors and cabinets.

The "strange" case of faith engagement casts light upon the dynamics of British urban governance more generally. The explicit challenge presented by faith engagement disrupts the discursive common sense of urban governance. In so doing, it reveals the specificity (and contestability) of dominant 
assumptions and behaviors. Faith engagement breaks "the bounds of normal discourse" (Morgan 1986, 11) in urban governance. Indeed, the case illuminates the narrative dissonance that is at the heart of the new urban governance, as it brings together an evermore diverse cast of actors from different social, economic, and cultural milieus.

Faith engagement is a critical case in understanding the ongoing renegotiation of boundaries between the state and civil society and between the public, private, and personal. The passion of the faith discourse provides a sharp contrast to the instrumentalism of the policy narrative and the managerialism of the partnership story. Faith actors are a disruptive presence at the urban governance table. Faith narratives challenge the assumptions of a "domain of rational deliberation that can be clearly marked from the passions and pleasures of the personal" (Newman 2007, 31). Faith engagement challenges dominant assumptions about what constitutes good governance. Perhaps trust is as important as accountability? How can long-term commitment be balanced against short-term performance targets? Could claims of social justice trump those of due process? Can policy take account of joined-up people as well as of joined-up government?

Our analysis of faith engagement suggests that narrative dissonance may actually prove to be a positive phenomenon within urban governance. Concepts of situated agency and narrative tradition are not intended to imply that actors are fixed or stuck in their specific discourses. As Bevir and Rhodes (2006) note, "change arises as situated agents respond to novel ideas or problems" (p. 5). Individuals pursue beliefs and perform actions through a reasoning that is embedded in the tradition they inherit but that is also shaped by interactions with other narrative traditions and social contexts. The existence of multiple narratives is not necessarily a negative phenomenon; over time, they may form the building blocks of a new "discourse coalition" (Hajer 1993, 47). The encounter between faith actors and those more normally associated with urban governance may yet prove productive in the fashioning of what Newman (2007) calls a new "public imaginary" (p. 42) and Rhodes (1997) a "new governing code" (p. 110). But surfacing different narratives and interrogating the tensions between them is a vital first step in seeking to harness that potential creativity.

\section{Notes}

1. Faith engagement in governance has received very little scholarly attention in comparison to faith-based service delivery, where there exists a major body of work, albeit focused on the United States. For an analysis of national-level strategies, see Dionne and Chen (2001), 
Formicola, Segers, and Weber (2003), Black, Koopman, and Ryden (2004), and Wuthnow (2004). For urban and community-based research, see Vidal (2001), Sherman (2002), Canada (2003), and Government Accountability Office (2006).

2. See 2001 census, Leicester City Council Web site, www.leicester.gov.uk/your-councilservices/council-and-democracy/city-statistics (accessed January 31, 2008).

3. Gerry Stoker (1995) argues that this "blending of capacities between governmental and non-governmental actors" (p. 69) is akin to processes associated with urban regime theory. More recently, Jonathan Davies (2004) has counseled against such "conceptual stretching" on the basis that British urban partnerships are characterized by limited business engagement and tight control by central government (pp. 30-31). Clarence Stone (2004) proposes that such partnerships may constitute "weak regimes," in the context of a comparative research agenda that focuses on how "governing arrangements take shape" in different urban contexts (pp. 9-12).

4. Comparisons with the United States are interesting here. Religious commitment features far less in the rhetoric of British politics. As one of Tony Blair's closest advisers, Alistair Campbell, famously put it, "We don't do God" (http://observer.guardian.co.uk/comment/ story/0,6903,949023,00.html [accessed January 31, 2008]). But at the same time, there is less anxiety about breaching the "wall" between church and state (Towey 2004, 212). Although a far more secular society than the United States, Britain has an established church with a constitutional role, including the presence of Bishops in the House of Lords. It appears that the historic permeability of the church-state boundary may make the inclusion of faith actors in urban governance (over and above service contracting) more acceptable, even (ironically) where these actors come from non-Christian faiths. Indeed, a comparative European study has linked relatively high levels of "state accommodation of Muslims" to the specific character of church-state relations in Britain (Fetzer and Soper 2005, 146-47). Thanks to Professor Ken Wald, University of Florida, for drawing our attention to this point when we presented an earlier version of the article at the annual meeting of the American Political Science Association, Chicago, August 30-September 2, 2007.

5. Further methodological details (including topic guides) can be found in an appendix to the full research report at http://www.dmu.ac.uk/faculties/business_and_law/business/research/ lgru/lgru_faith_groups.jsp (accessed February 8, 2008).

6. Further methodological details (including topic guides) can be found in an appendix to the full research report at www.jrf.org.uk/bookshop/eBooks/9781861348388.pdf (accessed February 8, 2008).

7. Interview with civil servant in Department of Communities and Local Government, February 2005.

8. Interview with Church of England activist, February 2005.

9. Interview with Muslim community leader, February 2005.

10. Interview with Church of England activist, February 2005.

11. Interview with Local Strategic Partnership faith representative, February 2005.

12. Interview with Council of Faiths representative, February 2005.

13. Interview with civil servant in U.K. Home Office, February 2005.

14. Interview with Council of Faiths representative, February 2005.

15. Interview with Council of Faiths representative, February 2005.

16. Interview with Sikh community leader, February 2005.

17. Interview with Muslim community leader, February 2005.

18. Interview with Muslim community activist, February 2005. 


\section{References}

Atkinson, R. 2000. Narratives of policy: The construction of urban problems and policy in the official discourses of the British government, 1968-1998. Critical Social Policy 20 (2), 211-32.

Baker, C. 2007. Religious literacy, faithful capital and language. Paper presented to Economic and Social Research Council Faith and Civil Society Seminar, Anglia Ruskin Univ., Cambridge, UK, January 23.

Bevir, M. 2005. New labour: A critique. Abingdon, UK: Routledge.

Bevir, M., and R. Rhodes. 2003. Interpreting British governance. Abingdon, UK: Routledge. 2006. Governance stories. Abingdon, UK: Routledge.

Black, A., D. Koopman, and D. Ryden. 2004. Of little faith: The politics of George W Bush's faith-based initiatives. Washington, DC: Georgetown Univ. Press.

Blunkett, D. 2004. New challenges for race equality and community cohesion in the $21 \mathrm{st}$ century. Speech to the Institute of Public Policy Research, London, July 7.

Burns, N., K. Schlozman, and S. Verba. 2001. The private roots of public action. Cambridge, MA: Harvard Univ. Press.

Canada, B. 2003. Faith-based organizations and their relationship with state and local governments: Analysis of recent initiatives. Washington, DC: Congressional Research Service.

Cantle, T. 2005. Community cohesion: A new framework for race and diversity. Basingstoke, UK: Palgrave Macmillan.

- 2007. If faith is the new "race," is faithism the new racism? Paper presented to Economic and Social Research Council Faith and Civil Society Seminar, Anglia Ruskin Univ., Cambridge, UK, January 23.

Commission on Integration and Cohesion. 2007. Our shared future. London: Communities and Local Government.

Commission on Urban Life and Faith. 2006. Faithful cities: A call for celebration, vision and justice. London: Methodist Publishing House and Church House Publishing.

Community Cohesion Panel. 2004. The end of parallel lives? The report of the Community Cohesion Panel. London: Home Office.

Crouch, C., and D. Marquand. 1995. Reinventing collective action. Oxford, UK: Basil Blackwell.

Church Urban Fund. 2006. Faithful representation: Faith representatives on Local Public Partnerships. London: Church Urban Fund.

Davies, J. 2004. Can't hedgehogs be foxes too? Reply to Clarence Stone. Journal of Urban Affairs 26 (1): 27-33.

Dinham, A. 2007. Priceless; unmeasureable? Faiths and community development in twentyfirst century England. London: Faith Based Regeneration Network.

Dionne, E., and M. Hsu Chen. 2001. Sacred places, civic purposes. Washington, DC: Brookings Institution.

Erlandson, D. 1993. Doing naturalistic enquiry: A guide to methods. London: Sage.

Fetzer, J., and C. Soper. 2005. Muslims and the state in Britain, France, and Germany. Cambridge, UK: Cambridge Univ. Press.

Formicola, J., M. Segers, and P. Weber. 2003. Faith-based initiatives and the Bush administration. Lanham, MD: Rowman and Littlefield.

Furbey, R. 2006. Faith engagement: Cuddlesome or troublesome? Paper presented to Faiths and Civil Society Seminar, Anglia Ruskin Univ., Cambridge, UK, May 11. 
Furbey, R., A. Dinham, R. Farnell, D. Finneron, and G. Wilkinson. 2006. Faith as social capital: Connecting or dividing? Bristol, UK: Policy Press and Joseph Rowntree Foundation.

Giddens, A. 1998. The third way. Cambridge, UK: Polity.

Government Accountability Office. 2006. Faith-based and community initiative. GAO-06616. Washington, DC: Government Accountability Office.

Hajer, M. 1993. Discourse coalitions and the institutionalization of practice. In The argumentative turn in policy analysis and planning, edited by F. Fischer and J. Forester, 43-76. London: Univ. College London Press.

Home Office. 2004. Working together: Co-operation between government and faith communities. London: Stationery Office.

- 2005a. Citizenship survey. London: Home Office.

2005b. Improving opportunity, strengthening society: The government's strategy to increase race equality and community cohesion. London: Home Office.

Huxham, C., ed. 1996. Creating collaborative advantage. London: Sage.

Jameson, F. 1989. The political unconscious: Narrative as a socially symbolic act. London: Routledge.

Leicester City Council (2004) Embracing the present, predicting the future: Social action by the faith communities of Leicester. Leicester, UK: Leicester City Council.

Local Government Association. 2002. Faith and community. London: Local Government Association.

London Churches Group. 2002. Regenerating London: Faith communities and social action. London: London Churches Group for Social Action.

Lowndes, V., and R. Chapman. 2005. Faith, hope and clarity: Developing a model of faith group involvement in civil renewal. London: Home Office.

- 2006. Faith, hope and clarity: Developing a model of faith group involvement in civil renewal. In Re-energising citizenship: Strategies for civil renewal, edited by T. Brannan, P. John, and G. Stoker, 163-84. Basingstoke, UK: Palgrave.

Lowndes, V., L. Pratchett, and G. Stoker. 2006. Local political participation: The impact of rules-in-use. Public Administration 84 (3): 539-61.

Lowndes, V., and H. Sullivan. 2004. Like a horse and carriage or a fish on a bicycle: How well do local partnerships and public participation go together? Local Government Studies 30 (1): 52-74.

National Council for Voluntary Organisations. 2007. Faith and voluntary action. London: National Council for Voluntary Organisations.

Neighbourhood Renewal Unit. 2004. References to faith communities in government documents. London: Neighbourhood Renewal Unit.

New Deal for Communities. 2000. Faith community workshops in NDC partnerships. London: Department of the Environment, Transport and the Regions, New Deal for Communities.

Northwest Regional Development Agency. 2005. Faith in England's Northwest. Warrington, UK: Northwest Regional Development Agency.

Office of the Deputy Prime Minister. 2005. Report on the 2004 survey of all English LSPs. London: Office of the Deputy Prime Minister.

Office of National Statistics. 2004. Focus on religion. London: Office of National Statistics.

Morgan, G. 1986. Images of organisation. London: Sage.

Newman, J., ed. 2005. Remaking governance. London: Sage.

. 2007. Rethinking "the public" in troubled times. Public Policy and Administration 22 (1): 27-46. 
Putnam, R. 2000. Bowling alone: The collapse and revival of American community. New York: Simon \& Shuster.

Rhodes, R. 1997. Understanding governance. Buckingham, UK: Open Univ. Press.

Sherman, A. L. 2002. Empowering compassion: The strategic role of intermediary organizations in building capacity among and enhancing the impact of community transformers. Indianapolis, IN: Hudson Institute.

Stoker, G. 1995. Regime theory and urban politics. In Theories of urban politics, edited by D. Judge, G. Stoker, and H. Wolman, 54-71. London: Sage.

- 2004. Transforming local governance: From Thatcherism to new Labour. London: Palgrave Macmillan.

Stone, C. 2004. It's more than the economy after all: Continuing the debate about urban regimes. Journal of Urban Affairs 26 (1): 1-19.

Sullivan, H., and C. Skelcher. 2002. Working across boundaries. Basingstoke, UK: Palgrave.

Towey, J. 2004. Faith and the public square. In One electorate under God? edited by E. Dionne, J. Bethke Elshtain and K. Drogosz, 212-6. Washington, DC: Brookings Institution.

Verba, S., K. Schlozman, and H. Brady. 1995. Voice and equality: Civic voluntarism in American politics. Cambridge, MA: Harvard Univ. Press.

Vidal, A. 2001. Faith-based organizations in community development. Washington, DC: Department of Housing and Urban Development.

Wuthnow, R. 2004. Saving America: Faith-based services and the future of civil society. Princeton, NJ: Princeton Univ. Press.

Dr. Adam Dinham is a reader in social policy; director of the Faiths and Civil Society Unit, Anglia Ruskin University, Cambridge, United Kingdom (www.faithsunit.org); and visiting professor at the University of Calgary, Canada. His research explores the roles and relationships between faiths and other actors in the public realm, particularly in relation to community development and social action. He is the coeditor, with Rob Furbey and Vivien Lowndes, of Faith in the Public Realm (Policy Press, forthcoming). Recent publications include Faith as Social Capital: Connecting or Dividing? with R. Furbey, A. Dinham, R. Farnell, D. Finneron, and G. Wilkinson (Joseph Rowntree Foundation, 2006).

Vivien Lowndes is a professor of local government studies at De Montfort University, Leicester, United Kingdom. She previously worked at the Universities of Essex and Birmingham as well as in local government and the voluntary sector. Professor Lowndes is the author of numerous articles on local government, urban partnerships, and citizen participation. She is the coeditor, with Adam Dinham and Rob Furbey, of Faith in the Public Realm (Policy Press, forthcoming). She has conducted research on faith engagement in urban governance for the U.K. Home Office and is now leading an action research project on the prevention of violent extremism in three United Kingdom cities. 